\title{
HORTA NO ESPAÇO ESCOLAR: PRÁTICAS PARA A ALIMENTAÇÃO SAUDÁVEL E CONSERVAÇÃO AMBIENTAL, NO COLÉGIO ESTADUAL JARDIM PAULISTA EM ARAGUAÍNA-TO
}

Horta in the school space: practices for healthy eating and environmental conservation, at the state college jardim paulista in Araguaina-TO

Horta en el espacio escuela: practicas para la alimentacion saludable y la conservacion ambiental, en el colegio Estatal Jardim Paulista en Araguaína-TO

\author{
Daniela Mendes Barbosa ${ }^{1}$, Karoline Pires ${ }^{1}$, Leandra Belarmino da Costa $^{1}$, Amadeus Viera \\ Soares $^{2}$, Antônia Marcia Duarte Queiroz ${ }^{3}$ \\ ${ }^{1}$ Curso de Geografia na Universidade Federal do Tocantins, Araguaína, Brasil. \\ ${ }^{2}$ Professor de Geografia, Diretoria Regional de Educação de Araguaína, Brasil \\ ${ }^{3}$ Professora Adjunta, Curso de Geografia, universidade Federal do Tocantins, Araguaína, Brasil
}

\section{Artigo recebido em 10/04/2020 aprovado em 15/04/2020 publicado em 18/04/2020.}

\section{INTRODUÇÃO}

O projeto de intervenção pedagógica realizado no Colégio Jardim Paulista, é resultante do projeto maior da Residência pedagógica e visa proporcionar aos estudantes a compreensão da importância de uma alimentação saudável e, sobretudo o uso adequado do ambiente. Com o objetivo de aproveitar e revitalizar a horta na escola em um espaço que já existia, mas não era explorado, além disso melhorar a arborização da escola e promover maior conforto aos estudantes.

Assim, elaboramos o projeto para intervir nessa realidade, como uma nova maneira de uso do local, como o plantio de sementes e de árvores frutíferas, repassando aos estudantes a sua importância e a sua utilidade para a escola e para eles. O projeto foi desenvolvido em três etapas, sendo a primeira, a revitalização da área, a qual todos nós contribuímos de alguma maneira, limpando os canteiros adubando, dentre outros.

$\mathrm{O}$ intuito do projeto foi impulsionar e motivar aos estudantes ao reconhecimento da importância da horta para a escola. Para que eles possam estender essa ideia e prática da horta para suas casas, como também criar novas hortas em outros locais ou até mesmo incentivar outras pessoas, ultrapassando para além do espaço escolar.

Dessa forma, o desenvolvimento do projeto foi de suma importância, principalmente aos estudantes que obtiveram a experiência de ter o contato com uma horta, sabendo que muitos deles nunca tiveram esta oportunidade, além de adquirir conhecimentos teóricos, somando para a formação educacional.

\section{METODOLOGIAS E MATERIAIS}

Contamos com o auxílio do livro didático, artigos, livros e publicações como base na elaboração do projeto, contamos com o apoio do colégio em doar adubos e sementes para a reconstrução da horta. A parte teórica foi realizada através de palestra, sobre alimentação saudável, o aproveitamento de alimentos típicos da região e uso consciente do Ambiente.

A parte prática do projeto foi por meio da revitalização da área reservada à horta e o plantio das mudas de árvores. Foi realizada a limpeza dos canteiros, a adubação e a reserva de recipiente para armazenar e realizar a compostagem de restos de 
alimentos da merenda escolar e outros. O replantio de sementes na horta e a compostagem de restos de alimentos da merenda escolar para produção de adubo orgânico.

Contamos com a participação efetiva dos estudantes nas etapas práticas da ação, de plantio da horta e de mudas de árvores frutíferas na escola.

\section{RESULTADOS E DISCUSSÃO}

O projeto possibilitou a compreensão aos estudantes sobre alimentação saudável, cultivo da horta na escola e que trouxe benefícios tanto para os estudantes e para a escola-campo quanto para nós residentes enquanto acadêmicos de geografia. Proporcionou um conhecimento mútuo para todos os envolvidos nesta ação de intervenção pedagógica.

Figura 1 Projeto de intervenção pedagógica- Colégio Jardim Paulista



Fonte: Arquivo pessoal (QUEIROZ, A.M.D. 2019).

Consideramos que a horta trouxe benefícios para os estudantes que compreenderam e se sensibilizaram sobre a sua importância. Também, para a escola-campo que pode utilizar dos produtos produzidos no espaço escolar. Observamos diversos benefícios para todos os envolvidos, a medida que abordamos temas relacionados ao ambiente pudemos contribuir para o entendimento em torno da educação ambiental.

Sabemos que a educação ambiental ainda é pouco desenvolvida nas escolas. Um exemplo disto é que quando fazíamos perguntas aos estudantes, durante a palestra sobre ambiente, horta e alimentação saudável poucos sabiam ou tinham conhecimento sobre o assunto. Ou seja, este projeto veio para mudar este cenário, ensinar aos estudantes como hábitos saudáveis podem contribuir para a sobrevivência do planeta, mantendo a sensibilização destes para preservar e conservar o ambiente, no qual todos nós estamos inseridos.

O projeto da Horta no espaço escolar se destacou e serviu como um modelo a ser seguido e desenvolvido por outras escolas no estado.

Reafirmamos que é de suma importância os estudantes obterem o conhecimento sobre a educação ambiental que envolve a alimentação saudável, livre de agrotóxicos e seus poluentes. A horta, por sua vez expõe aos estudantes da escola-campo o interesse sobre a conservação do ambiente, sua importância, o uso deste ambiente e sobre a alimentação saudável.

\section{CONCLUSÃO}

$\mathrm{O}$ projeto foi realizado em conjunto com a comunidade escolar e universidade. $\mathrm{O}$ que mais nos motivou a elaborar este projeto foi sem dúvidas o olhar geográfico para o uso do espaço, no qual não estava sendo utilizado de maneira que atendesse a necessidade da escola e o olhar enquanto licenciando, ao observar a falta de conhecimento dos estudantes a respeito da horta.

O objetivo de chamar a atenção para a necessidade de uma alimentação saudável, a partir da produção de alimentos de forma sustentável atingiu a sua finalidade, ao instigar e sensibilizar os estudantes sobre o não uso de agrotóxicos para a plantação de 
alimentos e pode mostrar que o consumo de alimentos com agrotóxicos desencadeia uma série de prejuízos para a saúde.

Além disso, demos ênfase sobre a educação ambiental, como algo muito importante a ser promovido com os discentes e a comunidade, pois serviu e serve para aproximá-los da realidade e criar hábitos sustentáveis de alimentação. Trazer tais concepções aos estudantes do sexto ao nono ano faz com que eles obtenham conhecimentos e possam até mesmo despertar o interesse em consumir alimentos orgânicos e elaborar uma horta com legumes, verduras e frutas no seu próprio espaço familiar.

Os resultados ultrapassaram nossas expectativas, pois esperávamos que os estudantes participassem de todas as ações, mas eles, realmente foram ativos, participando desde a palestra até o plantio das sementes e árvores, assim concluímos que as atividades foram de suma importância para o lado da nossa profissionalização e para a vida pessoal.

Esse contato com a prática no espaço escolar nos proporcionou grandes e novas experiências e expectativas para quando formos lecionar e a boa produtividade em trabalho coletivo, nos forneceu aprendizados para além da teoria acadêmica.

\section{AGRADECIMENTO}

A CAPES; A Universidade Federal do Tocantins; Ao Colégio Estadual Jardim Paulista; A Diretoria Regional de Educação de AraguaínaDREA.

Todos os autores declararam não haver qualquer potencial conflito de interesses referente a este artigo.

\section{REFERÊNCIAS}

BRASIL. Ministério da Educação. Secretaria da Educação Básica. Base Nacional Comum CurricularBNCC. Brasília, DF, 2016. n. 600. Disponível em: http://basenacionalcomum.mec.gov.br/ Acesso em: 18/10/2019.

DIAS, R.A. Estudo de caso e caracterização: projeto educando com a horta escolar - Planaltina, DF, 2017.p.27. Disponível em: http://www.bdm.unb.br/bitstream/10483/19628/1/201 7. Acesso em: 18/10/2019.

MORGADO, Fernanda da Silva. A horta escolar na educação ambiental e alimentar: experiência do Projeto Horta Viva nas escolas municipais de Florianópolis. 2006.

RIBEIRO, Wagner Costa. Por dentro da Geografia, $6^{\circ}$ ao $8^{\circ}$ ano/Wagner Costa Ribeiro.p.224-3. Ed.-São Paulo: Saraiva, 2015.

ZAMBERLAM, Jurandir. Agroecologia: caminho de preservação do agricultor e do meio ambiente/ Jurandir Zamberlam, Alceu Froncheti.p.54 Petrópolis, RJ: Vozes, 2012 